\title{
Infiltrasi Neutrofil pada Tikus dengan Periodontitis setelah Pemberian Ekstrak Etanolik Kulit Manggis
}

\author{
Rendra Chriestedy Prasetya*, Nunuk Purwanti", dan Tetiana Haniastuti** \\ *Fakultas Kedokteran Gigi Universitas Jember \\ ** Fakultas Kedokteran Gigi Universitas Gadjah Mada \\ *Jalan Kalimantan No. 37, Kampus Tegalboto, Jember, Jawa Timur, Indonesia 68121; e-mail: rendrachriestedy@gmail.com
}

\begin{abstract}
ABSTRAK
Periodontitis adalah inflamasi kronis yang disebabkan oleh bakteri periodontopatogen. Pada periodontitis terjadi peningkatan infiltrasi neutrofil yang berfungsi untuk memfagositosis bakteri yang menginfiltrasi jaringan gingiva. Kulit manggis mempunyai bahan aktif yaitu xanton yang mempunyai efek antiinflamasi dengan jalan menghambat sintesis PGE2 sehingga akan menurunkan infiltrasi sel inflamasi. Penelitian ini bertujuan untuk mengetahui infiltrasi sel neutrofil pada periodontitis setelah pemberian ekstrak etanolik kulit manggis. Tikus wistar jantan sebanyak empat puluh delapan ekor diinduksi periodontitis dengan ligasi pada daerah subgingiva gigi anterior rahang bawah selama 7 hari. Setelah hari ke-7, ligasi dilepas selanjutnya tikus dibagi menjadi 4 kelompok perlakuan yaitu ekstrak kulit manggis $30 \mathrm{mg} / \mathrm{kg}$ BB dan $60 \mathrm{mg} / \mathrm{kg} \mathrm{BB}$, ibuprofen dan saline. Tikus dikorbankan pada hari ke-1, 3, 5 dan 7 setelah perlakuan. Jaringan pada bagian anterior rahang bawah ditanam dalam paraffin dan dilakukan pemotongan serial kemudian diwarnai dengan hematoxylin eosin. Jumlah neutrofil dihitung di bawah mikroskop dengan perbesaran 400x. Data jumlah neutrofil dianalisa dengan Two Way Anova. Hasil Two Way Anova menunjukkan perbedaan yang bermakna rerata sel neutrofil antar kelompok perlakuan $(p<0,05)$ mengindikasikan pemberian ekstrak etanolik kulit manggis berpengaruh terhadap jumlah sel neutrofil. Dapat disimpulkan bahwa pemberian ekstrak etanolik kulit manggis mampu menurunkan infiltrasi sel neutrofil pada tikus yang diinduksi periodontitis.
\end{abstract}

Maj Ked Gi. Juni 2013; 20(1): 33-38.

Kata kunci: periodontitis, ekstrak etanolik kulit manggis, neutrofil

ABSTRACT: Neutrophil infiltration in rats with periodontitis after the granting of Ethanolic Extract Skin Mangosteen. Periodontitis is a chronic inflammatory disease caused by periodontopathic bacteria. When periodontitis occurs are followed by neutrophil infiltration. Mangosteen rind contains xanthone, an anti-inflammatory substance which inhibits the synthesis of PGE2 and therefore reduces inflammatory cells infiltration. This research aimed to study neutrophil cells infiltration in experimental-induced periodontitis rats after mangosteen rind ethanolic extract administration. Fortyeight male wistar rats were induced the periodontitis by putting silk ligature subgingivally around the neck of the anterior lower teeth for seven days. After the ligation had been taken out, the rats were divided into four groups and treated orally with mangosteen rind extract $60 \mathrm{mg} / \mathrm{kg} \mathrm{BB}, 30 \mathrm{mg} / \mathrm{kg} \mathrm{BB}$, ibuprofen, and saline. The rats were sacrificed on the $1^{\text {st }}, 3^{r d}$, $4^{\text {th }}$, seven $n^{\text {th }}$ day after the treatment. Their anterior lower jaws were processed for paraffin embedded tissue, cut serially and stained with hematoxylin-eosin. The neutrophil cells were observed and counted under the microscope (400x). The data were analyzed using Anova. Anova result showed a significant difference among group $(p<0,05)$ indicating that mangosteen rind ethanolic extract affected the number of neutrophils. In conclusion, mangosteen rind ethanolic extract reduced the number of neutrophil infiltration in periodontitis rats.

Maj Ked Gi. Juni 2013; 20(1): 33 - 38.

Keywords: periodontitis, mangosteen rind ethanolic extract, neutrophil

\section{PENDAHULUAN}

Periodontitis merupakan inflamasi pada jaringanperiodontalyangditandaidengankehilangan perlekatan dan kerusakan tulang alveolar. Faktor utama penyebab periodontitis adalah bakteri Gram negatif anaerob terutama Agregatibacter actynomicetemcommitans, Porphyromonas gingivalis dan Prevotella intermedia. ${ }^{1}$ Pada periodontitis terjadi infiltrasi sel neutrofil. Neutrofil merupakan sel yang pertama kali migrasi dari pembuluh darah saat terjadi inflamasi yang berperan sebagai pertahanan dari tubuh untuk memfagosit mikroorganisme yang masuk. Sel ini bermigrasi dari pembuluh darah dan berada di jaringan selama 2-4 hari sesudah dimulainya inflamasi akut. Migrasi neutrofil dari dalam pembuluh darah disebabkan oleh mediator kimiawi yang dilepaskan oleh jaringan yang mengalami inflamasi. ${ }^{2}$ 
Tanda klinis periodontitis adalah terjadi inflamasi gingiva (perubahan warna dan tekstur gingiva), pembentukan poket, kehilangan perlekatan periodontal dan kehilangan tulang alveolar. Gingiva penderita periodontitis menjadi lebih lunak dan berwarna merah mengkilat, stippling pada gingiva cekat menghilang, terjadi mobilitas gigi, margin gingiva yang membulat atau berbentuk kawah serta disertai dengan resesi gingiva. ${ }^{3}$

Perawatan periodontitis meliputi terapi mekanis yang ditunjang pemberian obat-obatan antibiotika dan antiinflamasi. Terapi mekanis yang dilakukan yaitu pembersihan karang gigi (scaling) dan penghalusan permukaan akar (root planning), bertujuan untuk menghilangkan deposit keras maupun lunak yang melekat pada permukaan maupun akar gigi yang digunakan sebagai tempat perlekatan dan pertumbuhan bakteri. ${ }^{1}$

Obat antiinflamasi yang biasa digunakan dalam terapi penyakit periodontal adalah antiinflamasi golongan non steroid yaitu ibuprofen dan flurbiprofen. Obat-obat tersebut berperan untuk meredakan rasa sakit dan mencegah perluasan inflamasi dengan menghambat pembentukan prostaglandin melalui jalur siklooksigenase (COX) metabolisme asam arakhidonat. Namun, penggunaan obat anti COX-2 dalam jangka panjang akan menyebabkan efek samping stomach ulcer dan hemorrhage. ${ }^{4}$ Adanya efek samping yang ditimbulkan akibat penggunaan obat antiinflamasi jangka panjang maka perlu dicari alternatif bahan yang lebih aman antara lain berasal dari tumbuhan herbal. Salah satu bahan yang dapat digunakan adalah buah manggis terutama kulit buahnya.

Manggis sangat digemari di Indonesia namun selama ini kulit buah manggis selalu dibuang. Kulit buah manggis ternyata mengandung bahan yang mempunyai khasiat farmakologis antara lain sebagai antibakteri, antiinflamasi, antioksidan dan antikanker. Kulit buah manggis ini memiliki khasiat farmakologi yang lebih tinggi dibandingkan bagian tanaman manggis lainnya. Kulit manggis mengandung beberapa komponen yang mempunyai aktivitas farmakologi antara lain senyawa golongan xanton yang termasuk di dalamnya $\alpha$-mangostin dan $y$-mangostin. ${ }^{5}$ Gamma mangostin berperan sebagai antiinflamasi mempunyai rumus kimia 1,3,6,7-tetrahidroksi-7 tetrahidroksi-2,8-bis(3-metil2-butenil)-9H-xanten-9-on. ${ }^{6}$ Penurunan jumlah PGE2 melalui COX-2 inhibitor mampu menghambat inflamasi pada penyakit periodontal. ${ }^{7}$

Ekstrak kulit manggis mampu menghambat aktivasi NF-kB yang menyebabkan penurunan aktivasi sitokin proinflamasi yaitu IL-1 dan TNF- $\alpha$ pada tikus yang diberi diet kolesterol. Interleukin 1 dan TNF- $\alpha$ merangsang sel endotel untuk memproduksi IL-8 dan platelet activating factor yang berperan dalam proses rolling leukosit dan menginduksi adhesi leukosit dengan endotel pembuluh darah sehingga leukosit keluar dari pembuluh darah dan menuju ke tempat terjadinya jejas. ${ }^{8}$ Penelitian ini bertujuan untuk mengkaji pengaruh pemberian ekstrak etanolik kulit manggis terhadap infiltrasi sel neutrofil gingiva pada tikus yang diinduksi periodontitis.

\section{METODE PENELITIAN}

Seluruh prosedur penelitian telah disetujui oleh komisi etik Fakultas Kedokteran Gigi Universitas Gadjah Mada Yogyakarta dengan diterbitkannya surat no. 2425/IX/EC/2012. Buah manggis yang didapatkan dari pasar tradisional di kota madiun diidentifikasi di Laboratorium Biologi Farmasi Fakultas Farmasi Universitas Gadjah Mada. Pembuatan ekstrak kulit manggis dilakukan di LPPT unit I UGM Yogyakarta. Buah manggis yang digunakan adalah kulit buah yang buahnya sudah masak. Kulit buah manggis yang telah terkumpul dibersihkan dari kotoran-kotoran, kemudian dirajang kecil-kecil dan dikeringkan dengan suhu 45 derajat Celcius selama 48 jam, kulit yang telah kering digiling hingga menjadi serbuk simplisia. Metode ekstraksi yang digunakan adalah metode perkolasi menggunakan pelarut etanol. ${ }^{9}$

Hewan coba yang digunakan dalam penelitian ini adalah 48 ekor tikus wistar jantan umur 2 bulan, berat badan 175-200 yang diperoleh dari Laboratorium Farmakologi Fakultas Kedokteran Universitas Gadjah Mada Yogyakarta. Sebelum diinduksi periodontitis, tikus dianastesi dengan diinjeksi ketamine $\mathrm{HCl}$ secara intramuskular pada 


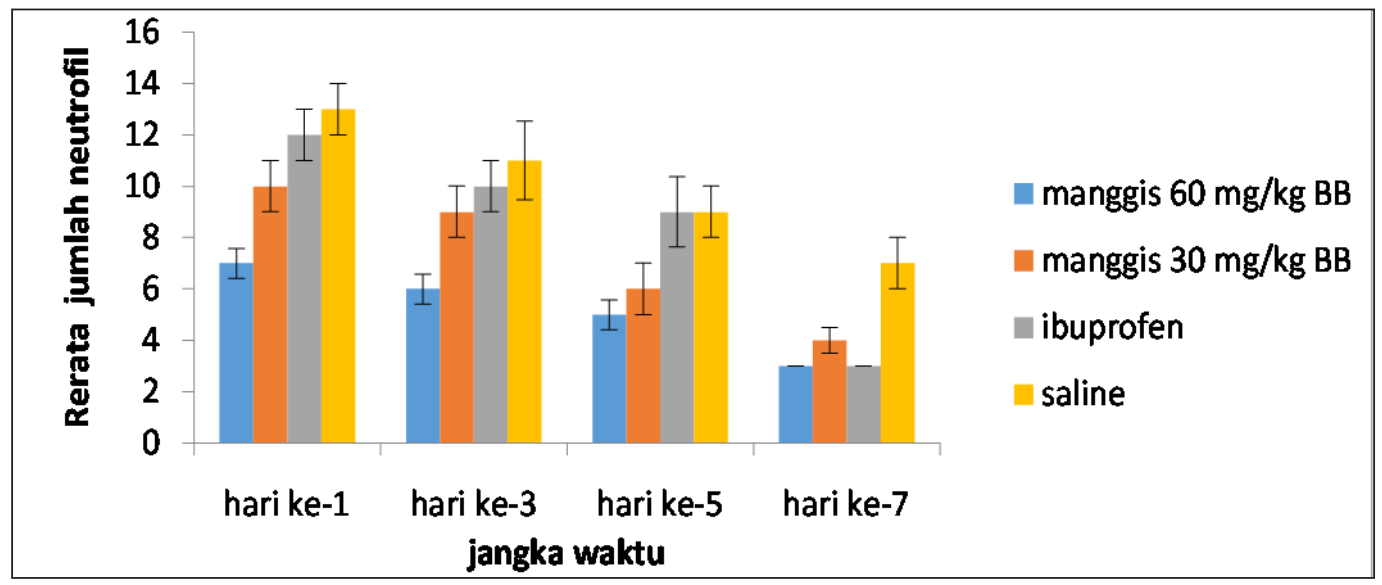

Gambar 1. Rerata dan simpangan baku jumlah neutrofil pada kelompok tikus periodontitis yang diberi perlakuan

Tabel 1. Rangkuman hasil uji Two-way Anova jumlah neutrofil

\begin{tabular}{lll}
\hline Source & $\mathrm{F}$ & Sig \\
\hline Hari & 22,56 & $0,00^{*}$ \\
Kelompok & 48,22 & $0,00^{*}$ \\
Kelompok-hari & 8,41 & $0,00^{*}$
\end{tabular}

${ }^{*}=$ berbeda bermakna $(p<0,05)$

otot paha belakang dengan dosis $0,2 \mathrm{ml} / 200 \mathrm{gram}$ berat BB. Induksi periodontitis dilakukan dengan mengikat benang dari sutra (silk ligature) ukuran 3,0 pada daerah subgingiva di sekeliling gigi incisivus anterior rahang bawah. Pada hari ke-7 ligasi dilepas kemudian tikus dibagi menjadi 4 kelompok perlakuan yaitu kelompok yang diberi ekstrak kulit manggis dosis $60 \mathrm{mg} / \mathrm{kg} \mathrm{BB}$, kelompok yang diberi ekstrak kulit manggis dosis $30 \mathrm{mg} / \mathrm{kg} \mathrm{BB}$, kelompok kontrol positif yang diberi ibuprofen $9 \mathrm{mg} / \mathrm{kg}$ BB dan kelompok kontrol negatif yang diberi saline $0,5 \mathrm{ml}$. Pemberian perlakuan secara per oral sehari 3 kali dengan menggunakan oral gavage pada masingmasing kelompok tikus. ${ }^{10}$

Pada hari ke-1, 3, 5, dan 7 setelah perlakuan, hewan dikorbankan dengan cara dekapitasi. Rahang bawah pada bagian gigi anterior yang telah diberi perlakuan diambil dan difiksasi dengan buffered formalin $10 \%$ selama 24 jam. Spesimen kemudian didekalsifikasi menggunakan EDTA $10 \% \mathrm{pH} 7,4$ selama 6 minggu pada suhu 4 derajat Celcius. Setelah lunak, spesimen ditanam dalam parafin, dan dipotong serial dengan ketebalan $5 \mu \mathrm{m}$ untuk dilakukan pengecatan hematoksilin eosin.
Sel neutrofil dihitung di bawah mikroskop dengan pembesaran 400 kali. ${ }^{11}$ Tiap preparat diamati pada tiga lapangan pandang berbeda pada daerah sulkus gingiva dan jaringan ikat di bawah epitel junctional dan epitel sulcular. Hasil pengamatan dihitung rata-ratanya dan dianalisis dengan Two way Anova dan LSD.

\section{HASIL PENELITIAN}

Hasil penelitian menunjukkan penurunan rerata jumlah neutrofil pada semua kelompok perlakuan seiring bertambahnya hari pengamatan (Gambar 1).

Hasil uji normalitas dan homogenitas menunjukkan bahwa data mempunyai nilai signifikansi 0,06 berarti data terdistribusi secara normal dan homogen. Data kemudian diuji parametrik dengan menggunakan uji Two-way Anova didapatkan hasil bahwa terdapat perbedaan bermakna antar jumlah neutrofil pada masingmasing hari, kelompok perlakuan dan interaksi antar hari pengamatan dan kelompok perlakuan $(p<0,05)$. 
Tabel 2. Rangkuman hasil uji LSD jumlah neutrofi

\begin{tabular}{lcccc}
\hline \multicolumn{1}{c}{ Kelompok } & Hari ke-1 & Hari ke-3 & Hari ke-5 & Hari ke-7 \\
\hline Manggis 60mg-30mg & 3,67 & 1,00 & 0,00 & 1,00 \\
Manggis 60 mg-ibuprofen & 6,67 & 0,33 & 1,33 & 2,77 \\
Manggis 60 mg-saline & 8,33 & 3,67 & 8,33 & 0,67 \\
Manggis 30 mg-ibuprofen & 3,00 & 0,67 & 1,33 & 1,67 \\
Manggis 30 mg-saline & 0,88 & 4,00 & 4,33 & 5,67 \\
lbupofen saline & 0,88 & 0,67 & 5,67 & 4,00 \\
\hline
\end{tabular}

Untuk mengetahui perbedaan antar masingmasing kelompok perlakuan dilakukan uji LSD (Tabel 2).

\section{PEMBAHASAN}

Pada penelitian ini dilakukan induksi periodontitis pada tikus dengan cara mengikatkan benang dari sutra (silk ligature) ukuran 3,0 pada daerah subgingiva di sekeliling gigi incisivus anterior rahang bawah agar terjadi akumulasi dental plak. $^{10}$ Tujuh hari setelah ligasi, secara klinis tampak tanda-tanda periodontitis yaitu warna margin gingiva kemerahan, kontur margin gingiva yang membulat dan terjadi penurunan margin gingiva (resesi gingiva). Ligasi bertujuan agar terjadi akumulasi dental plak yang akan menginduksi terjadinya periodontitis. Setelah ligasi akan terbentuk dental plak yang tersusun antara lain oleh bakteri Veilonella parvula, Parmivonas micra, Streptococcus mitis. ${ }^{12}$

Komponen bakteri Gram negatif yaitu lipopolisakarida (LPS) akan menginduksi terjadinya inflamasi pada jaringan periodontal gigi. Prosesnya diawali dengan ikatan antara LPS dengan toll like receptor 4 pada makrofag. Ikatan tersebut akan memicu NF-kB di dalam makrofag yang selanjutnya menginduksi sekresi sitokin proinflamasi antara lain IL-1 dan TNF- $\alpha$. Interleukin-1 dan TNF- $\alpha$ akan menginduksi vasodilatasi sehingga terjadi peningkatan permeabilitas pembuluh darah. $\mathrm{Di}$ dalam pembuluh darah, IL-1 dan TNF- $\alpha$ menginduksi ekspresi molekul adhesi endotel yaitu vascular cell adhesion molecule-1 (VCAM1) dan intercelluler adhesion molecules 1 (ICAM1). Vascular cell adhesion molecule-1 akan berikatan dengan integrin $\alpha 4 \beta 1$ (VLA4) reseptor pada permukaan leukosit. Intercelluler adhesion molecules 1 akan berikatan dengan integrin dari leukosit yaitu LFA-1 dan MAC-1. Kedua molekul diatas berfungsi dalam proses adhesi leukosit di dalam pembuluh darah yang kemudian akan berdiapedesis dari pembuluh darah. Leukosit yang pertama kali migrasi ke jaringan adalah neutrofil. Neutrofil berfungsi untuk melakukan fagositosis terhadap bakteri dan produknya. Inflamasi yang ditandai dengan migrasi neutrofil ke jaringan disebut inflamasi akut. Inflamasi akut hanya berlangsung singkat oleh karena neutrofil mempunyai waktu hidup yang pendek saat berada di jaringan (short life), maka apabila inflamasi masih berlanjut fungsinya akan digantikan oleh monosit. Monosit berdiapedesis dari endotelium menuju ke jaringan menjadi makrofag untuk melakukan fagositosis. ${ }^{13}$

Interleukin-1 dan TNF- $\alpha$ yang dihasilkan oleh makrofag juga akan menyebabkan lepasnya fosfolipid dari membran sel epitel gingiva, fibroblas, sel mast, neutrofil sehingga terjadi metabolisme asam arakhidonat oleh kerja enzim fosfolipase A2. Siklooksigenase (COX-2) jumlahnya meningkat saat terjadi inflamasi dan berperan dalam sintesis prostaglandin terutama PGE2. ${ }^{14}$ Peningkatan ekspresi COX-2 akan meningkatkan sintesis PGE2. Peningkatan sintesis PGE2 akan menyebabkan peningkatan vasodilatasi dan permeabilitas endothelium yang berakibat meningkatkan infiltrasi sel inflamasi. ${ }^{1}$

Hasil penelitian ini menunjukkan bahwa pemberian ekstrak kulit manggis 60 dan $30 \mathrm{mg} / \mathrm{kg}$ BB pada tikus yang diinduksi periodontitis mampu menurunkan infiltrasi sel inflamasi. Penurunan jumlah sel inflamasi terutama neutrofil pada kelompok yang diberi ekstrak kulit manggis diduga disebabkan oleh aktivitas dari kandungan kulit 
manggis. Kulit manggis mengandung bahan yang berperan antiinflamasi yaitu senyawa golongan xanton yang termasuk di dalamnya alfa mangostin dan gamma mangostin. ${ }^{5}$ Gamma mangostin dari kulit buah manggis mampu menghambat ekspresi MAPK, NF-KB dan AP-1 dalam makrofag. ${ }^{15}$ Hambatan ekspresi MAPK, NF-KB dan AP-1 akan menurunkan sekresi IL-1 dan TNF- $\alpha$ yang berakibat menghambat vasodilatasi dan permeabilitas endotel sehingga menurunkan jumlah neutrofil yang keluar menuju ke jaringan.

Efek antiinflamasi ekstrak kulit manggis $60 \mathrm{mg} /$ $\mathrm{kg}$ BB lebih baik dibandingkan ekstrak kulit manggis $30 \mathrm{mg} / \mathrm{kg}$ BB. Hal ini kemungkinan disebabkan oleh komponen senyawa yang terkandung dalam kulit manggis terdiri dari gabungan beberapa senyawa kimia yang saling bersinergi. ${ }^{16}$ Komponen yang terkandung dalam kulit manggis antara lain triterpenoid, xanton, vitamin B1, kalsium dan zat besi. Senyawa paling utama adalah golongan xanton yaitu alfa mangostin, beta mangostin, gamma mangostin, mangostanol dan gartanin. ${ }^{5}$ Kesimpulan penelitian bahwa ekstrak etanolik kulit manggis mampu menurunkan infiltrasi sel nutrofil pada tikus yang diinduksi periodontitis.

\section{KESIMPULAN}

Berdasarkan hasil penelitian dapat ditarik kesimpulan bahwa ekstrak kulit manggis mampu menurunkan jumlah sel neutrofil pada tikus yang diinduksi periodontitis dibandingkan kelompok kontrol. Saran yang dapat diberikan, perlu penelitian lebih lanjut tentang bahan aktif yang spesifik dari kulit manggis serta efek penghambatannya pada sekresi IL-1 dan TNF- $\alpha$ yang mampu memberikan efek antiinflamasi pada tikus yang diinduksi periodontitis.

\section{DAFTAR PUSTAKA}

1. Carranza F, Henry H, Newman, Michael G. Clinical periodontology. $10^{\text {th }}$ Ed New York: WB Saunders; 2006. h. 263-7.

2. Gehrig SJ, Wilmann DE. Foundation of periodontics for the dental hygienist. Illionis: Wolter Kluwer; 2008.
3. Lindhe J, Karring $\mathrm{T}$, Lang PN. Clinical periodontology and implant dentistry. $4^{\text {th }} \mathrm{Ed}$. Oxford: Blackwell Publishing Ltd; 2003. h. 209-10.

3. Rateitschak EM, Wolf HF, Hassel, TM. Color atlas of periodontology. Thieme: Stutgart; 2007.

4. Chin YW, Jung HA, Chai H, Keller WJ, Kinghorn AD. Xanthones with quinone reductaseinducing activity from the fruits of Garcinia mangostana (Mangosteen). Phytochem. 2008; 69: 754-8.

5. Nugroho AE. Manggis (Garcinia mangostana I.): dari kulit buah yang terbuang hingga menjadi kandidat suatu obat. Yogyakarta: Farmasi UGM; 2011.

6. Queiroz AC, Souza de Lima. The antinociceptive and antiinflamatory activities of caulerpin a bisindole alkoloid isolated from seaveed of the gene caulerpin. Drugs. 2009; 689-704.

7. Sargowo D, Senorita A, Widodo A. Peranan ekstrak kulit manggis dalam penurunan kadar tnf- $\alpha$ dan IL-1 pada dislipidemia. Malang: Universitas Brawijaya Press; 2010.

8. Palestri S. Pengaruh variasi konsentrasi polivinil pirolidon(pvp) sebagai bahan pengikat terhadap sifat fisik tablet ekstrak etanolik kulit buah manggis (garcinia mangostana I.). Surakarta: Universitas Muhammadiyah; 2010.

9. Tsagareli W. Ultrastructural aspect of gingival soft tissue cells population under experimental gingivitis. Georgia: Tbilisi State Medical University; 2006.

10. Vahabi S, Rezazaden, Movagher SE, Nazemisalman B. Relationship between mast cell counts and different type of periodontitis. J. Periodontal Implant Dent. 2010; 2(2): 56-60.

11. Duarte MP, Tezolim RK, Figueiredo CL, Feres M, Bastus PM. Microbial profile of ligatureinduced periodontitis in rats. Arch Oral Biol. 2010; 55: 1142-7.

12. Kumar $\mathrm{V}$, Abbas $\mathrm{A}$, Fausto N. Pathologic basis of disease. New York: Elsevier. 2006: 48-69. 
13. Pasaribu F, Sitorus $P$, Bahri S. The test of ethanol extract of mangosteen (Garcinia mangostana $L$ ) to decrease blood glucose level. J Pharm Pharmacol. 2012; 1: 1-8.

14. Porth MC, Matfin G. Pathophysiology concept of altered health science. $8^{\text {th }}$ Ed. New York: Mosby; 2009.
15. Bungrumpert $A$, Kalpravidch $R$, Chuang $C$, Overman A, Martinez K, Kennedy A, McIntosh C. Xanthones from mangosteen inhibit inflammation in human macrophages and in human adipocytes exposed to macrophage condition media. J Nutr. 2010; 16: 342-47. 